\title{
More than surviving, thriving in the information age: reading as a basis for using information technology efficiently
}

\author{
JOHN ROYCE \\ International School, Hamburg, Germany, email: \\ 100272.410@compuserve.com
}

\begin{abstract}
Within recent years, computer technology has revolutionized information production, information storage, and information retrieval. Information is available in unprecedented quantity, easity and quickly obtained, often inexpensively.

The patterns of work are changing; leaming how to leam becomes more necessary than ever for survival.

Standard information-handling skills and strategies and a range of technical skills will enhance the chances of success, but reading skills are fundamental. We can leam from the skills exhibited by good readers and good users of information; awareness of the habits of poor readers and information-users will help us help them cope in an increasingly information-glutted world.
\end{abstract}

Once upon a time and not so long ago, the problem was information underload. Even if the knowledge was out there, published and available somewhere, it was not necessarily available to the inquirer at the moment of need. Poorly resourced and poorly staffed school and public libraries compounded the problem. Slater (1987) suggests that many who do not or who cannot use a library have been conditioned by unsuccessful library experience, probably at school. Information failure leads to information blindness; there are too many cases on record of wheels being reinvented because of library reluctance and lack of information-handling skills. As the saying goes, "Two years hard graft in a laboratory can often save several hours research in the library."

Within the past few decades, the position is reversed-at least as far as the availability of information and knowledge is concerned. Computer technology has revolutionized information production, it has revolutionized information storage, and it has revolutionized information retrieval. Information is available in many forms and in many formats, in unprecedented quantity; it is more easily and quickly obtained, and often more cheaply.

In the western world, publishing is a growth industry; sales are increasing, library borrowing is increasing, reading is increasing. In the United States, book sales to adults increased by $25 \%$ between 1991 and 1995. In those same years, computer-related book sales increased by $150 \%$ (Heath, 1997), many of which were those 1,000 page guides needed to explain the bits that the manuals leave out, make obscure or gloss over. As of a

Education for All: Culture, Reading and Information, IASL, 1998 
few years ago, the literature of mathematics is estimated to be doubling every ten years, and that of physics every six years (Irving, 1985).

And the books are being read. Three-quarters of American parents spend more time reading to their children than their parents read to them (Heath, 1997).

In the UK, children's public library borrowing rose by $6 \%$ between 1990 and 1994, and rose as a proportion of all public library borrowing in those years (Cross, 1997). Heavy library borrowers are also heavy book buyers; "The only real tell-tale sign, it seems, is that they were hooked we still young. Most loved reading as a child." ("Early reading...," 1996).

This is all to the good. Research shows that readers become readers by reading. It shows that reading assists in language development. It shows that readers learn better and learn faster than non-readers and poor readers.

The research consistently points to four factors which make for lifelong readers:

- hearing stories and other literary pieces read aloud, from infancy through to and beyond school

- $\quad$ sustained, silent, self-selected reading

- role-models, people who clearly believe that books and reading are important

- interest and enjoyment.

The need for an early start is confirmed yet again in two recent studies. In an American study, the Herbs found a relationship between how much children have been read to and how well they will read; and yes, they also found that active reading with the child, talking about the story and the pictures, really does influence future literacy development (Bailow, 1997). Meanwhile, children in the ongoing Bookstart study in England have now started primary school. The latest findings show that children in the reading group are speaking and listening and reading and writing better than the children in the non-reading control group, are already surging ahead in math and other school subjects (Chouri, 1997; see also Cullinan, 1992, Trelease, 1984, and many others).

Krashen's survey of research studies shows that FVR (free voluntary reading) results in better reading comprehension, writing style, vocabulary, spelling, grammatical development. FVR makes for favorable attitudes towards reading. FVR readers read more. Krashen (1993, p.5) affirms, "Reading as a leisure activity is the best predictor of comprehension, vocabulary, and reading speed."

The research shows too the other side of the coin: children who do not read are disadvantaged in terms of reading comprehension, writing style, vocabulary, spelling, grammatical development, and all those other reading and learning skills.

The publishing boom has been fueled by computer technology, and while traditional print publishing has expanded in recent years, non-print publishing has positively exploded. CD-ROM publishing has expanded between 25 and 50\% a year over the last decade, and no-one knows the size of the Internet. Gray (1996) shows the World Wide Web increasing four-iold every six months between 1993 and 1996, and Darrow's (1997) later estimate shows that the pace is maintained. To put some scale to that: for every million pages on the web today, there will be two million in three months time, four million in six months, 
eight million in nine months, 16 million web pages just a year from today. And this is just the Web-not the 'net!

It is estimated that the amount of information in the world is doubling every two years (Darrow, 1997). While not everything which is published represents new knowledge, what we know and what we think we know is increasing exponentially. Furthermore, new knowledge often discounts, proves false or makes obsolete old knowledge; knowledge has a half-life, and it is diminishing.

Clearly, the potential for information overload is real. Information overload can occur in the traditional library or resource center, but it is a more sedate process. The catalogue might point to several or several dozen different areas of the library; Reader's guide to periodical literature or similar index might suggest twenty or 200 possibilities to check out; browsing may serendipitously reveal undreamed-of-treasures. Electronic information offers a totally different scale to the problem. Electronic communications enable us to obtain more information than we can handle, seemingly at the speed of light.

Information overload is a real problem-for those who do not have suitable information-handling strategies. Indeed, many information seekers do not even realize they have a problem. A piece of action research published in Book Report last year showed that each of 8 groups of tenth-grade students found more information in 20 minutes on their set topics using electronic resources than they did in 20 minutes using traditional print resources, nearly 1000 electronic sources as against under 200 (Hare, 1997). Not a word about the quality or the relevance or the currency-feel the weight.

It is very easy to be stunned by the glitz and the sheer speed of electronic information.

Consider the Encyclopedia Britannica. The complete set costs more than $\$ 1,500$, weighs 118 pounds, and takes up more than four feet of shelf space. A commensurate encyclopedia on CD-ROM-Microsoft's Encarta, for instance-costs $\$ 99.99$, holds up to 650 megabytes of data, weighs under an ounce, and could it in your purse (Lyall, 1994).

Encarta is, in many ways and especially for school uses, a better choice of encyclopedia than Britannica-but commensurate is a moot point.

Many are so overwhelmed by the sheer volume of electronic information that they give up - or are forced to give up. On the one hand, many information professionals say that the major advantage of email and the Internet is the ability to communicate, directly or indirectly, with the world, and especially with those who have the information they need to solve other people's information problems (Basch, 1996). On the other hand, the average worker in a large corporation receives a daily 177 messages, by phone, fax, email, post-it, voice mail. Many cannot handle the volume and deal only with the messages which appear most urgent-a tactic which tends to increase communication as correspondents try desperately to make themselves heard-or read. (Tanaka, 1997: Kleiner, 1997). The problem is so bad that some firms have taken to restricting the times at which their staff can access and reply to their email (Tetzeli, 1994).

We can put this in the context of changing work patterns. The nature of work is changing. New technologies are changing the demographics of the workplace. Some industries die as they become uneconomic; others no longer require hordes of unskilled, manual laborers 
or semi-skilled clerical workers, but may rely instead on just a few well-trained machine operators or computer operators. Those still employed take on new roles and new skills. In many cases, what these modern managers suffer is not information overload but work overload, as they attempt to do their ex-secretary's job as well as their own, in their meaner, leaner, slimmed-down, down-sized, intranetted company. After all, a secretary does far more than type. A good secretary acts as a filter, sifting what needs to be dealt with by her manager, passing on to the appropriate person matters best dealt with elsewhere, and dealing with much communication herself. Yet even the overwhelmed secretary-less information-bombarded can use standard time-management and information-handling strategies to reduce that overload.

The nature of work is changing. Business gurus suggest that one may change career direction five or six times during one's lifetime, and each career change may require a measure of retraining. Even within the same career, the half-life of knowledge and the burgeoning of new technologies demands that we keep up-to-date in our professional knowledge and expertise. The lifelong learning movement aims to give students the skills to go on learning throughout life and also positive attitudes towards leaining which accept and even welcome change and new learning.

One of the most valuable things, some would say the most important thing, that schooling should give to students is the ability to learn and go on learning throughout life. In this way, information skills can be thought of as the most important basic skills of all and that as members of a democratic society it is everyone's right to expect that these will be taught.

With the increasing need for re-current education and job re-training, and the inevitable increase in individualized, computerized and de-institutionalized learning, it is more crucial than ever that people learn how to learn during their years of formal schooling (Teaching students how to learn, 1986, p.8).

To survive the information explosion, new abilities are required, but these are mainly of a technical nature, connected with technology: hardware and software. Those who have learned how to learn will survive and thrive. Standard information-handling strategies will work, simply because they are basic, generic strategies, applicable to any information problem; they will work equally well in electronic and in print environments.

The old, well-tried strategies hold good: information users still have to determine what is needed and then locate and access it, select and reject it, synthesize and present it; if learning is to take place, they must reflect upon the information process as well as on the information obtained; real learning involves, at the least, the transformation of information into knowledge.

My thesis is that good readers and able users of information in the print environment will survive and thrive in the information technology environment. Teachers and librarians can learn from and teach the strategies and techniques used by good readers, and those used by good users of information. The strategies and techniques used by poor readers and poor users of information need also to be studied, the better to take remedial action and the better to prevent their faults and practices being adopted by those just setting out.

Reading is fundamental. Reading is a basic survival skill. Modern society could not have evolved without reading and, of course, writing. Writing enables us to record information 
and ideas; textual records can be indexed. Writing (in its various forms) gives the record permanence. Oral records are subject to change, for whatever reason, and no-one may be any the wiser; with the written record all who can read can refer to the same, unchanging record. Writing gives permanence; reading enables lasting learning.

We need to teach and to practice the skills used by good readers. Good readers have strategies for choosing what they read and how they read. They vary their reading techniques and strategies according to their purpose in reading and the difficulty of the material being read, an amalgam of language, purpose, and prior knowledge. Reading for pleasure, be the text imaginative or informational, is performed in ways very different to reading to extract quick reference information and again in a different way to reading for study purposes. Someone reading a how-to-do-it manual will read differently to someone revising for an exam, and someone reading to remember a part in a play reads differently to someone looking for statistical information.

Good readers use different reading techniques with different kinds of material. They read at different speeds according to the difficulty of the material; when looking for quick facts they scan the text, when trying to get an idea of the text, the level of language used or the prior knowledge expected they may skim a chapter or the entire book, when reading to learn or to understand they will read more carefully, though not necessarily more slowly.

Reading specialists distinguish between receptive, reflective and rejective reading.

Receptive reading makes few demands upon the reader: the vocabulary and the structures are within the reader's grasp and the material is based on the reader's prior experience. There is usually a narrative story-line which pulls the reader along, although receptive reading can take place with information books, as when the reader already knows much about the subject. Receptive reading yields wonderful dividends. As Krashen shows, recreational reading, free voluntary reading, is both enjoyable and good for you.

Reflective reading occurs when the reader thinks about the text as $s /$ he is reading; the reader may stop to think about what is being said, may turn back to a previous page or chapter, may refer to another text or his/ her notes before returning to the original. This approach is used by someone who has some prior knowledge of a subject but is by no means an expert.

Rejective reading takes place when the subject matter is so difficult to understand or so outside the reader's experience that little is understood. Often the text seems to be well within the reader's grasp, yet there remains little understanding.

Lunzer and Gardner (Neate, 1992) have shown that while schools are often effective in basic reading skills and in promoting receptive reading (especially when pre-school groundwork has been laid), they are often less good at teaching reflective reading skills as in reading for information. In consequence and despite students' apparent survival, much school reading is rejective.

In the same way, schools are often good at teaching low-level information skills: find out all about the Second World War, or anything you can find out about China. Now that information is so readily available, in books and magazines, on CD-ROMs and on the Internet, students can find enormous amounts of material and can photocopy, or download and printout, more than enough to satisfy an unaware teacher. Schools are not always so good at setting tasks which require the transformation of information, at getting 
children to answer real questions, at having them find connections and exceptions or contrasts and similarities. Research is not just about finding out, it is finding evidence, and many children do not get enough opportunity to do this (Mckenzie, 1993, 1997).

These skills, reading skills and information-handling skills, do not necessarily come of themselves. They need to be taught and they need to be practiced, and the groundwork cannot be started too early.

We must here recognize that electronic technology makes new demands on the reader; reading in the electronic environment is NOT exactly equivalent to reading print. One of the advantages-and one of the disadvantages-of electronic information is its non-linear form; one can jump from one page to another, from one web-site to another, seamlessly and often with no means of returning to the original page; this suits some learning styles, but many do feel uncomfortable with the lack of sequence. Again, multimedia affords instant pictures and sounds to supplement the text, a great advantage to those who prefer such modes of communication (Moeller, 1997). Whatever one's preferred thinking style or dominant form of intelligence, the screen or monitor can make a tremendous difference to one's reading speed and understanding: Muter (1991) has shown that skimming can be more than $40 \%$ slower from a screen than from a printed page, and poor quality screens slow the reading speed and diminish one's understanding of the material being read.

Reading, and especially reading for enjoyment, is the key. Unfortunately, many people, children and adult, feel that reading is work, and hard work at that. Reading is often associated with school, with tests and homework (Trelease, 1984). Because it is hard work, they do not enjoy reading, so they do not put in a lot of practice, so they do not improve as readers, so they do not do a lot of it and it remains hard work.

In a recent study, Beers (1996) distinguished three kinds of aliterate illiterate? reader: dormant, uncommitted and unmotivated. She offers three sets of strategies which a librarian or teacher might use to help each kind of reader to read more. The strategies are different because the reasons for their reading reluctance are different. Amongst other things, she found that uncommitted and unmotivated readers in particular lacked a reading or book background at home, bedtime stories had been uncommon when they had been younger, the family just did not talk about books. These children had never discovered that books were fun, nor that reading is an enjoyable activity. This is a standard finding.

One of the strategies commonly used for helping uncommitted and unmotivated readers, one which worked for Beers' too, is to ask such readers to choose from a small selection of books.

Mackey and Johnston (1996) make a similar point: their recent study of book resistant readers confirmed that many readers are overwhelmed when they come into a library. They just do not know where to start. They have not learned the strategies by which more practiced readers narrow their choices and make their selections, such techniques as reading more by a known author, getting a friend's recommendation, following a genre or a series, looking at covers, and so on. The research team found that book resisters read more, and they read more successfully, when they were encouraged to discuss strategies for choosing, and also when they were presented with a small selection from which to make their reading choices.

There are important lessons for us here. As with readers, so with information users. 
Able users of information develop strategies for finding, choosing and using information. Their strategies are built upon three skills areas: reading, information-handling, and technical. The skills are interdependent and often practiced simultaneously; their boundaries merge and overlap.

Able users of information recognize that they cannot study every document of interest which comes their way; they recognize also the diminishing returns to be gained from new information. They know where they are going, they know what they need to find out and what they need to do to get there.

Able users of information relate what they need to find out with what they already know. They ask questions and brainstorm. They prioritize. They relate the amount of information needed to the time available. They know when and how much is enough; they can visualize their answers or responses, they have a grounding in their subjects. They recognize when they need to spiral back, to question an earlier finding, to question their own premises. They know that research can be circular, as they begin to find out what they did not know that they needed to know; their minds are open, they have half-an-eye out for the serendipitous discovery which might lead them down undreamed-of-but pertinent-byways. These are all standard information handling skills. Many are also skills exhibited by readers who actively engage in and with the texts and the reading matter.

On the other hand, many less able information users share major problems: they are not sure what they are looking for, they have poor selection and rejection skills, and they do not know when or even whether they have found the information for which they are looking, even when they have found it! These are sometimes problems of language comprehension but they are often due to lack of basic comprehension of the subject or topic. The need for prior knowledge, an understood overview in the light of the task at hand, is paramount.

I am sure that we all have horror stories to relate, about the child who borrows several books on birds because he needs to find out four different ways to cook eggs; about the student studying the Great Depression who goes to the on-line catalogue, types in the single-word DEPRESSION, and spends the next hour reading the opening chapters of a book called Coping with Depression; about the student researching China's one-child policy who rejects the article "China's missing girls", saying she is not interested in China's teenage runaway problem.

I particularly like the story of the two boys who looked for information about soccer star Eric Cantona in a CD-ROM encyclopedia; the search interface found no reference to Cantona, but found a number of entries containing the word Eric; the first article thrown up was on Eric the Red, which the lads decided was a variation of the Manchester United nickname, the Red Devils. So they dutifully printed out the article, glued beneath it a picture of the soccer player, and showed the librarian their work. She made them read it aloud; it began, "In about AD 982 a brawny, red-bearded Norseman named Eric set sail from the Northwest coast of Iceland..." (Drury, 1997).

The overview stage provides a framework for all stages of the research process, from knowing what needs to be done or found out, through knowing where to look and what to look for, to knowing what one has found out, and on to showing what one has found out. 
The overview stage allows one to maximize prior knowledge, even when the subject is completely new and prior knowledge is non-existent.

A good part of the choosing process is rejection, and the potentially overloaded information worker has to be able to choose which information is worth following-up and which is less likely to yield required information and so can be put aside for the moment or totally discarded. Skimping those early stages is a sure-fire route to information overload, for when you do not know what is needed, everything seems important, and anything may be misunderstood.

Another problem common to many less-able information users is that of appropriate reading strategies. Studies in speed-reading show that one understands more the faster one reads. Given the amount of material available through electronic publishing, speed-reading becomes an essential survival skill (Buzan, 1982; Cutler 1988). Although a search strategy may throw up 30 or 300 or 300,000 hits, one does not need to read them all. Much of the information provides clues for the wary searcher, including the title, the opening lines quoted, and the addresses; hits may show the date of posting or when the search engine discovered the item. The author may be known, or the body responsible for publication. Just as a wary researcher will read blurbs and introductions and conclusions or summaries, note section headings and read first sentences of paragraphs, and so on, before tackling the main piece, the wary web researcher will attempt to find the equivalent of a table of contents, and perhaps follow a link or two.

Once a likely text has been found, on-line or off-line, the wary inquirer will again use speed-reading techniques, but where a non-electronic searcher must scan a text for his keywords, the electronic searcher can use the FIND function to track down those keywords and then read the surrounding sentences and the surrounding paragraphs. FIND can be used to give a quick indication of where and how many times a keyword is used in a document.

Standard speed-reading and survey techniques can also be used on electronic texts; good electronic authors give textual clues such as section headings and bolded words just as print authors do. Documents on CD-ROM often carry summaries of contents, and may include suggested keywords or descriptors, the better to aid new searches. Many clues are made obvious, there for the aware researcher to use, but researchers may need to be made aware of their usefulness.

Another difficult area is selection of authoritative resources. This problem may go unrecognized when information is scarce, but it is a very real problem when there is a glut of information from which to choose-because there is more to be rejected. A great deal of Internet material is sales material, selling goods or selling a viewpoint; much is vanity publishing, unrefereed. Evaluation techniques need to be taught and practiced. At the same time, appropriate resources must be chosen. Despite their lack of glamour, print resources and people resources are often more appropriate and up-to-date than electronic resources; nor must we forget that much electronic information is published for adults and often assumes a deal of prior knowledge.

Just as librarians and teachers often use small, pre-selected book collections to reduce the amount of choice with which reluctant, fragile readers are presented; less able information users can be provided with more opportunities for success while practicing electronic 
information-handling. CD-ROMs, videodisks, and other purchased materials will be pre-selected. Selected Internet sites can be "whacked" to provide off-line simulation of the on-line experience; on-line, choice can be directed through considered choice of hot-lists or bookmarked sites, whacked directories and similar preselections.

The efficiency and the effectiveness of reading skills and information handling skills will be enhanced by an armory of technical skills. Basic keyboarding skills are essential; use of the page-up and page-down keys, knowledge of standard Windows keyboard shortcuts, use of the number-pad, and so on. An understanding of search engines in general and favorite search engines in particular is needed, along with awareness that many accessible websites refuse entry to search engines; the searcher must know the URL or address. Searchers must know the difference between a keyword search and a subject search, and how to refine their search terms. A knowledge of a search engine's handling of Boolean terms is needed, along with awareness of less-used Boolean terms, and truncation and substitution forms as used by the favored search engine; they need to know about truncation and wild cards, to understand the effect that differences in spelling and language might have, to pick up and use specialist terms and jargon.

If students really are to learn how to learn, then they must be taught. There is a real need for teachers to model the various stages of the information-handling process, to think aloud, to demonstrate the ways they might tackle a problem and then to encourage discussion of the techniques the students could use or have used or would like to use.

Research strategies such as the Big Six (Eisenberg and Berkowitz, 1990) or the PLUS model (Herring, 1996) or the Research Cycle (McKenzie, 1997) will provide a basis for a grand amalgam of study and research strategies, critical thinking skills, and time management techniques. They provide a structured framework upon which inquirers at all stages and in all walks of life can rely. We must be careful, for different children have different learning styles, they react differently to various teaching styles, they utilize their various intelligences in different ways. We are dealing with individuals, and must never forget it. There is no one answer which will solve every educational problem.

At the same time, so much research points at the advantages of early reading experiences and there is little evidence to suggest that early exposure to books and print disadvantages a child (as long as the child is not expected or forced to read before he or she is ready); so much research points to the disadvantages of a late introduction to the books and reading experience and little to the advantages of a late start. When the evidence consistently points in just one direction, we do well to heed it. When the research consistently suggests the importance of early reading experiences, of reading aloud, of reading alone, of reading for enjoyment and of the importance of reading role-models, we do well to note and to act.

It all comes back to reading, and thus to the twin needs of getting readers hooked early in life, and that of providing plenty of practice, reading for information as well as reading for pleasure. You can survive in today's world, even if you can type with only one or two fingers. You can survive without ever using keyboard shortcuts or realising the full potential of your software. But even in a world of pictograms and icons, of sounds and pictures and Internet and intranets, you are going to find survival both difficult and expensive if your reading skills are poorly developed. 
Technology is not going to make reading obsolete; it is going to going to increase the need for good, basic reading skills. Reading skills, along with infornation-handling skills and technical skills, will enable information users not just to survive but to thrive in the information age.

\section{References}

Barlow, C.(1997). Ooooh baby, what a brain! School Library Journal, 43(7), 20-23.

Basch, R. (1996). Secrets of the super net searchers: the reflections, revelations, and hard-won wisdom of 35 of the world's top internet researchers. Wilton CT: Pemberton Press.

Beers, G.K. (1996). No time, no interest, no way!: the 3 voices of aliteracy. School Library Journal, 42(2), 30-33 and 42(3), 110-113.

Buzan, T. (1982). Use your head. London: British Broadcasting Corporation (2 ${ }^{\text {nd }}$. ed.).

Caragata, W. (1994). Information overload. Maclean's, 107(38), 60 if. (Ebsco MAS Item Number: 9409227503).

Cross, G. (1997). Who says children don't read?" Y.B.T. News, Summer, 5.

Cullinan, B.E. (1992). Read to me: raising kids who want to read. New York: Scholastic.

Cutler, W.E. (1988). Triple your reading speed. New York: Arco $\left(2^{\text {nd }}\right.$ ed).

Darrow, R. (1997. November 16) Harnessing the Internet: Use the Big Six! Available<http://www.clovisusd.k12.ca.us/library/BICSIX/b6intro.htm> (visited 1997, December 9).

Drury, C. (1997). Search, print and file!: CD-ROMs and the instant learning experience. School Librarian, 45(1), 10-11.

Early reading (1996). Early reading leads to hardback stuff (report on borrowing patterns revealed in Heavy book borrowers). Library Association Record, 98 (9), 438.

Eco, U. (1996). Why new media won't kill books. World Press Review, 43(6), June 1996, 16-17 (originally published in Cazeta Wyborcza, Warsaw, Feb. 24-25, 1996).

Eisenberg, M.B. \& Berkowitz, R.E. (1990). Information problem-solving: the big six skills approach to library and information skills instruction. Norwood NJ: Ablex.

Eisenberg, M.B. \& Berkowitz, R.E. (1997, October 12). Big six. The big six skills: information problem-solving approach to library and information skills instruction. Available<http://ericir.syr.edu/big6/home.html> (visited 1997, October 13).

Eskow, D. (1997). Beat information overload. PC World, 15(2), 149-162.

Ghouri, N. (1997). Books help babies to read-and count. The Times Educational Supplement, 21 November 1997, 1.

Hare, P.J. (1997). Technology helps students do more research better and faster. The Book Report, 15(4), 23-24. 
Heath, R.P. (1997). In so many words: how technology reshapes the reading habit. American Demographics, 19 (1), March 01, 1997, 39 ff. (Ebsco MAS Item Number: 9703260370 ).

Herring, J. (1996). Teaching information skills in schools. London: Library Association.

Irving, A. (1985). Study and information skills across the curriculum. (Heinemann Organization in Schools series.) London: Heinemann, 1985.

Keegan, V. (1996). Brain storms : just too much: why information overload is making us ill. The Guardian 2, 5 November 1996, 2-3.

Kleiner, K. (1997). I'm not here right now. New Scientist, 155 (issue 2095), 43.

Krashen, S. (1993). The power of reading: insights from the research. Englewood, CO: Libraries Unlimited.

Lyall, S. (1994). Are these books, or what? CD-ROM and the literacy industry. Technos, Winter 1994, 20-23. (Sirs Applied Science 1995, Article 40).

McKenzie, J. (1993, December). Grazing the net: raising a generation of free range students. From Now On, the Educational Technology Journal. Available<http://uww.fromnowon.org/dec93/grazing1.html> (visited 1998, March 30).

McKenzie, J. (1997, October). Launching student investigations. From Now On, the Educational Technology Journal. 1997.

Available<http://www.fromnowon.org/oct97/launch.html> (visited 1998, March 30).

Mackey, M. \& Johnston, I. (1996). The book resisters: ways of approaching reluctant teenage readers. School Libraries Worldwide, 2(1), 25-38.

Martin, J.M. (1996). Internet overload: disaster in the making? PC World, 46(10), 145-156.

Mellon, C.A. (1987). Teenagers do read: what rural youth say about leisure reading. School Library Journal, 33(6), 27-30.

Mind Tools Ltd. (1997, August). Using reading strategies to read more quickly and effectively. Mind Tools: how to think your way to an excellent life. Available<http://www.mindtool.demon.co.uk> (visited 1997, September 10).

Moeller, B. \& Hupert, N. (1997). Reading in the age of multimedia. Electronic Learning, May/June 1997, 54.

Monk, J., Davies, P. \& Karavis, S. (1992) Helping children access information from non-fiction books. Books for Keeps, 76, 20-21.

Muter, P. \& Maurutto, P. (1991). Reading and skimming from computer screens and books: the paperless office revisited? Behaviour and Information Technology, 10(4), 257-266. Available<http://psych.utoronto.ca/ muter/pmuter $2 . h t m>$ (visited 1998, March 30). 
Neate, B. (1992). Finding out about finding out: a practical guide to children's information books. Sevenoaks: Hodder and Stoughton.

Rifkin, G. (1995). The future of the document. Forbes, 156 (8), 9 October 1995 supplement, 42, ff. (Ebsco MAS Item Number: 9510097541).

Royce, J. (1997). Surviving information overload: lessons from research in reading reluctance. School libraries worldwide, 3 (2), 39-46.

Schrock, K. (1997, July 21). Critical evaluation surveys. Kathy Schrock's Cuide for Educators. Available<http://www.capecod.net/schrockguide/eval.htm> (visited 1997, September 5).

Setton, D. (1997). The E-mail never stops. Forbes, 160 (2) 18-; (Ebsco MAS Item Number: 9707230483).

Slater, M. (1987). Careers and the occupational image. Journal of Information Science, 13(6), 335-342.

Tanaka, J. (1997). Drowning in data. Newsweek, 129 (17), 85. (Ebsco MAS Item Number: 9705021683).

Teaching students how to learn: ideas for teaching information skills (2 ${ }^{\text {nd }}$ ed, 1986). Tasmania. Education Department of Tasmania.

Tetzeli, R. (1994). Surviving information overload. Fortune, 130 (1). 11 July 1994, 60, ff. (Ebsco MAS Item Number: 9406277617).

Trelease, J, (1984). The read-aloud handbook. Harmondsworth: Penguin.

White, H. (1997). The passion to be in fashion. Library Journal, 122(11), 48. (Ebsco MAS Item Number: 9706193384).

Willis, J. (1995). The age of multimedia and turbonews. Futurist, 29 (5), Sept/Oct 1995. 18, ff. (Ebsco MAS Item Number: 9509104137).

Woodward, R.B. (1996). Books are dead! Long live books! Village Voice, 41 (10), 5 March 1996, 26, ff. (Ebsco MAS Item Number: 9603116041 ). 